\title{
Changes in Scomberotoxin (Histamine) and Volatile Amine (TVB-N) Formation in Longtail Tuna (Thunnus tonggol) Stored at Different Temperatures
}

\section{Moza Abdallah Al-Busaidi”, Poulose Yesudhason, Khamis Saif Al-Falahi, Adel Khalifa Al-Nakhaili, Nashwa Ali Al-Mazrooei and Saoud Hamood Al-Habsi}

Fishery Quality Control Center, Ministry of Agriculture and Fisheries Wealth P.O. Box 427, P.C. 100, Muscat, Sultanate of Oman

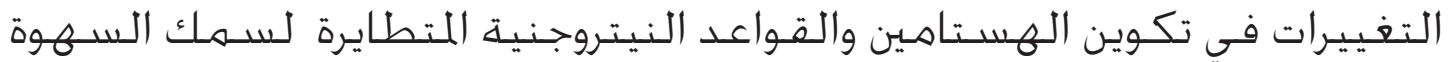

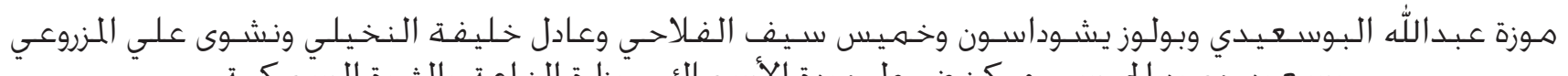

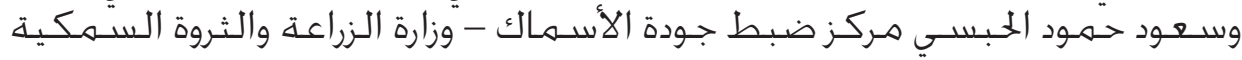

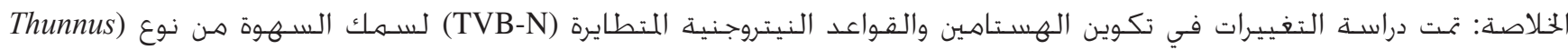

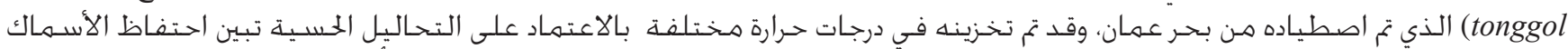

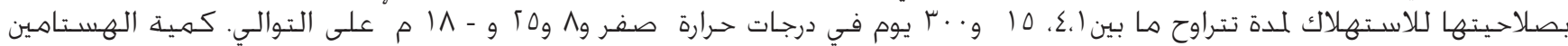

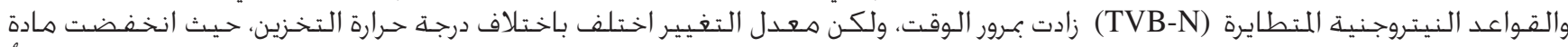

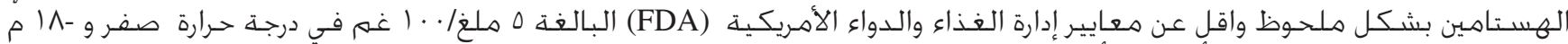

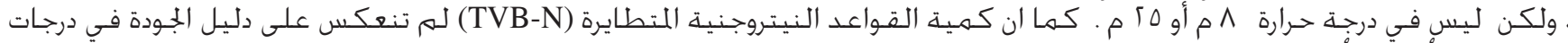

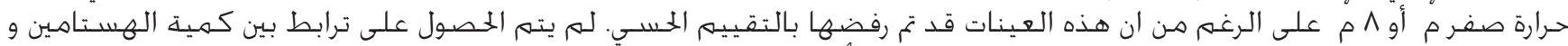

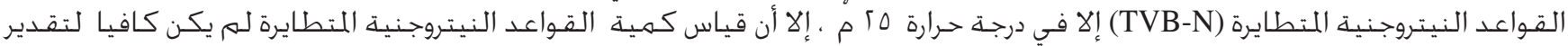

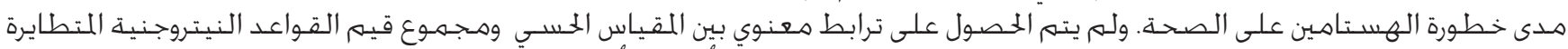
(TVB-N)

ABSTRACT: Changes in histamine and volatile amine (TVB-N) formation was studied in longtail tuna (Thunnus tonggol) captured in the Sea of Oman and stored at different temperatures. Based on sensory analysis, longtail tuna maintained shelf life for $1,4,15$ and 300 days at $0,8,25$ and $-18{ }^{\circ} \mathrm{C}$, respectively. Histamine and TVB-N increased with time, but the rate of change varied with storage temperature. Histamine formation was suppressed significantly at lower than the FDA limit of $5 \mathrm{mg} / 100 \mathrm{~g}$ at 0 and $-18^{\circ} \mathrm{C}$ but not at 8 or $25^{\circ} \mathrm{C}$. TVB-N did not reflect the quality index at 0 or $8{ }^{\circ} \mathrm{C}$ even though the samples were rejected by sensory evaluation. No correlation was observed between histamine and TVB-N values except at $25^{\circ} \mathrm{C}$ and assessment of TVB-N was not sufficient for estimating the degree of histamine-related health hazard. Poor correlation was found between sensory score and pooled TVB-N value compared to histamine, and the correlation was closer at 8 and $25^{\circ} \mathrm{C}$ than at the lower temperatures.

Keywords: Histamine, Longtail tuna, Scomberotoxin, Storage temperature, Safety.

\section{Introduction}

Human illness resulting from the consumption of food high in biogenic amines has generally been called histamine poisoning. Histamine food poisoning is one of the most frequently reported human illnesses associated with seafood (Dewaal et al., 2006). The condition is often referred to as scombrotoxic fish poisoning (SFP) or scombrotoxicosis because of its common association with fish in the family Scombridae. Scombrotoxic fish poisoning occurs throughout the world and the highest incidence is reported in the United States, Japan and the United Kingdom (Lehane and Olley, 2000). Histamine or scombrotoxic fish poisoning accounts for $5 \%$ of all food-related illness and $37 \%$ of all seafoodrelated illnesses reported to the CDC (Noltkamper, 2006). The most common symptoms of SFP include rash, flushing and sweating, burning of the mouth, nausea, vomiting, diarrhea, stomach pain, dizziness and swelling of tongue and face
(Murray and Hobbs, 1982). Fish belonging to the families Scomberesocidae and Scombridae are good candidates for histamine formation because of the high concentration of free histidine in muscle tissue (Ten Brink et al., 1990). However, non-scombroid fish have also been implicated (Bartholomew et al., 1987; Steve et al., 1989). Tuna (Thunnus) and mackerel (Scomber) have most frequently been involved, but this is partially due to the greater consumption of these fishes world-wide (Taylor, 1986). In September 1982, the FDA established a defect action level (DAL) for histamine in fish at $20 \mathrm{mg} / 100 \mathrm{~g}$ and in 1995 the FDA reduced the histamine DAL to $5 \mathrm{mg} / 100 \mathrm{~g}$. The reasoning for this reduction was due to the variability in histamine concentrations from section to section in a fish. If there is a $5 \mathrm{mg} / 100 \mathrm{~g}$ concentration of histamine in a sample, the FDA reasoned that there could be a sufficient concentration to cause illness $(50 \mathrm{mg} / 100$ g) in another section of the fish. The European community 
established that the average content of histamine in fish should not exceed $10 \mathrm{mg} / 100 \mathrm{~g}$ and no sample may contain more than $20 \mathrm{mg} / 100 \mathrm{~g}$ for fish belonging to Scombridae, Clupeidae, Engraulidae, Coryphaenidae, Pomatomidae and Scomberesocidae families (Commission Regulation 2073/2005/EC). Omani legislation (Ministerial Decision No.12/2009) has specified that histamine should not exceed $10 \mathrm{mg} / 100 \mathrm{~g}$. Shalaby (1996) recommended the following guideline levels for histamine content of fish: $<5 \mathrm{mg} / 100 \mathrm{~g}$ (safe for consumption): $5-20 \mathrm{mg} / 100 \mathrm{~g}$ (possibly toxic); $20-100 \mathrm{mg} / 100 \mathrm{~g}$ (probably toxic) and $>100 \mathrm{mg} / 100$ $\mathrm{g}$ (toxic and unsafe for consumption). Knowledge of the proximate composition of fish species has fundamental importance in the application of different technological processes and it is also an important aspect of the quality of raw material, sensory characteristics and storage stability (Sikorski, 1994). One of the most common chemical methods used for quality evaluation of fresh seafood is the evaluation of the total volatile bases fraction (TVB$\mathrm{N})$. The TVB-N includes ammonia, monoethylamine, dimethylamine along with trimethylamine (Yeh et al., 1978). Omani legislation (Ministerial Decision No.12/ 2009) has specified the TVB-N level for good quality fish is $25-35 \mathrm{mg} / 100 \mathrm{~g}$.

Tuna and tuna-like species are important due to their global economic importance and international trade for canning and sashimi, and are mostly consumed locally as fresh, frozen or canned. Longtail tuna (Thunnus tonggol) is one of the popular pelagic fish and accounts for a large proportion of fish production in the Sultanate of Oman. Although the fish has been rarely implicated in outbreaks of scombroid poisoning, there have been concerns for potential formation of histamine, since it belongs to the scombroid family, contains high level of histidine in the muscle and has high body temperature $\left(26-30{ }^{\circ} \mathrm{C}\right)$. Many studies have reported on the effect of storage temperature on histamine formation for various tuna species but results very often have been ambiguous with the level of histamine formation and shelf-life. (Guillen-Velasco et al., 2004; Silva et al., 1998; Guizani et al., 2005). Also, there is little or no knowledge relating to histamine levels in longtail tuna under various storage conditions. Histamine was measured and compared with volatile base nitrogen and sensory analysis in order to assess the effect of storage time and temperature.

\section{Materials and Methods}

\section{Sample Collection and Storage}

The fish samples used for the trials were 102 fresh longtail tuna (Thunnus tonggol) caught from the Sea of Oman and purchased at the landing centre, Muscat, Sultanate of Oman. Fish samples were stored on ice and kept in thermocole boxes and delivered to the laboratory within 45 minutes from the landing centre. Upon arrival at the laboratory, the length and weight of the fish were measured. The tuna fish were divided into four groups. One group $(\mathrm{n}=30)$ was stored at $0^{\circ} \mathrm{C}$ in ice (ice temperature). The second group $(n=27)$ of fish was stored at $8^{\circ} \mathrm{C}$ (home refrigeration temperature) in a temperature-monitored refrigerator. The third group $(n=6)$ was stored at $25 \pm 2{ }^{\circ} \mathrm{C}$ (room temperature representing the winter ambient temperature of Muscat and surrounding regions). The fourth group $(n=36)$ of fish was stored at $-18{ }^{\circ} \mathrm{C}$ (frozen storage temperature) using a temperaturemonitored-cooled incubator. Fish were placed individually in separate clean polythene bags and stored at respective temperatures. Good Manufacturing Practices (GMP) and Good Hygienic Practices (GHP) were strictly followed during the handling and storage at different temperatures of raw samples in order to avoid microbial growth and post-catch contamination. During storage, melting ice was replenished everyday in order to maintain a constant storage temperatures in ice-stored samples. Temperature was monitored regularly throughout the storage period with a digital thermometer.

Physical, chemical and sensory tests were performed on fresh longtail tuna samples prior to storage at different temperatures. Sampling was carried out at predetermined time intervals depending on the temperature of storage. Samples stored at 25,8 and $0{ }^{\circ} \mathrm{C}$ were analyzed on a daily basis. However, it is known that the deterioration progresses slowly at freezing temperatures, therefore, samples stored at $-18{ }^{\circ} \mathrm{C}$ were analyzed twice a week at the beginning of the storage and thereafter at two-month intervals for a period of up to 10 months. Triplicate samples were used for each analysis.

\section{Proximate analysis}

Moisture, ash, fat, and protein were determined following the AOAC (1993) methodologies (Sec 950.46, 938.08, 960.39, and 955.04, respectively).

\section{Histamine analysis}

Histamine was determined by the method of Taylor et al. (1978) with some modifications. Fish muscle (10 g) was homogenized with $20 \mathrm{ml}$ of $10 \%$ trichloroacetic acid (TCA) using a homogenizer (Nissei, Japan) for 2-3 $\min$. The homogenate was centrifuged at $3000 \mathrm{rpm}$ for $5 \mathrm{~min}$ and $20 \mathrm{ml}$ of the supernatant was filtered through a Whatman membrane filter and the $\mathrm{pH} \mathrm{5-7}$ was adjusted using a $10 \%$ sodium hydroxide solution. Twenty $\mathrm{ml}$ of 0.4 $\mathrm{M}$ acetic acid buffer was added to the $\mathrm{pH}$ adjusted solution and filtered through a column containing amberlite with $100 \sim 200$ mesh size (CG50). The column was washed with $80 \mathrm{ml}$ of $0.2 \mathrm{M}$ acetic acid buffer and $20 \mathrm{ml}$ of 0.2 $\mathrm{N} \mathrm{HCl}$. A total volume of $25 \mathrm{ml}$ was collected, filtered through a Whatman $(0.45 \mu \mathrm{m})$ membrane filter and $20 \mu \mathrm{l}$ was directly injected into the chromatograph.

The analysis was performed using a Waters Alliance High-Pressure Liquid Chromatography System (HPLC) model 2690 equipped with a quaternary pump, an online degasser and an injection valve with a loop capacity of $20 \mu \mathrm{l}$. The detector used was a Scanning Fluorescence 
Detector model 474 with a $330 \mathrm{~nm}$ excitation and 430 $\mathrm{nm}$ emission wavelengths. The histamine compound was determined using a reverse phase Shodex Asahipak column model ODP-50 (150 x $4.6 \mathrm{~mm})$. The isocratic mobile phase (18:82) consisted of acetonitrile (Sigma, $99.9 \%$ ) and $50 \mathrm{mM}$ Sodium tetraborate (Sigma, $99 \%$ ) aqueous solution containing $1 \mathrm{mM}$ O-phtal-aldehyde (OPA) (GR for fluorometry, Kiran light laboratory) and $1 \mathrm{mM}$ NAC (N-Acetyl-1-cysteine) was used at a flow rate of $0.5 \mathrm{ml} / \mathrm{min}$. The histamine peaks were integrated and calculated with Empower software. For each analysis, recovery samples were prepared and analysed and the mean recovery obtained was $95.5 \%$. Also, standard reference material of FAPAS canned tuna fish (SRM $\mathrm{T}$ 2711) was used to cross-check the reliability of the test. The mean value $(125 \pm 6.5 \mathrm{mg} / 100 \mathrm{~g})$ was within the range of the assigned value $(138 \pm 17.0 \mathrm{mg} / 100 \mathrm{~g})$ of histamine showed that the method was adequate for the analysis of histamine.

\section{Total Volatile Base Nitrogen (TVB-N) analysis}

TVB-N was determined using the method of Damoglu (1979). Fish muscle (10 g) was homogenized with 150 $\mathrm{ml}$ of distilled water, $2 \mathrm{~g}$ magnesium oxide, and 4 drops of silicon antifoam agent for $1 \mathrm{~min}$. using a Warring blender. The homogenate was transferred into a receiving flask and $25 \mathrm{ml}$ of $2 \%$ boric acid and 3 drops of methyl red indicator were added and the flask was placed into a BUCHI steam distillation unit consisting of Rotavapor model R-124, Vacuum controller model B-721 and Water-bath model B-480 (Switzerland). The mixture was steam distilled, $75 \mathrm{ml}$ of the volatile component collected and the level determined by titrating with $0.05 \mathrm{~N}$ sulfuric acid $\left(\mathrm{H}_{2} \mathrm{SO}_{4}\right)$.

\section{Sensory evaluation}

Sensory analysis was carried out by 7 semi-trained panelists. The panel evaluated the fish samples based on a hedonic scale with numerical scores of 7-1, 5-1 or 3-1 point scale using the assessment scheme from the Tasmanian Food Research Unit with slight modifications (Bremmer et al., 1987; Guizani et al., 2005). The inherent characteristics of longtail tuna such as gill colour, gill odour, round body, overall appearance, eye colour were evaluated (Table 1). Scores among panelists were averaged and tested statistically.

\section{Statistical analysis}

Results of physical, chemical and sensory analysis were analyzed using SPSS 10.0 (SPSS INC., Chicago, IL) software. Descriptive statistics of means, standard deviation, one way and two-way ANOVA, and correlation coefficient (Pearson's) were applied in analyzing the results. A significance level of $5 \%$ was used. The regression analysis between parameters was conducted by plotting scattered graphs and calculating the $\mathrm{r}^{2}$ factors. The $\mathrm{r}^{2}$ factors higher than 0.5 were accepted to indicate a correlation between chemical and sensory parameters.

\section{Results}

\section{Proximate Composition}

The average length and weight were $46.18 \pm 2.03 \mathrm{~cm}$ and $1.03 \pm 0.125 \mathrm{~kg}$, respectively. The results of the proximate composition of longtail tuna at different storage temperatures are presented in Table 2. The initial values for moisture, lipid, crude protein and ash were 72.5, 2.85, 23.19 and $1.52 \%$, respectively. In the present study, the values reported for moisture $(71.45,71.25,71$ and 73.05 $\%$ ), lipid $(3.02,3.22,4.48$ and $2.62 \%)$, protein (23.89, 24.0, 23.15 and $23.02 \%)$ and Ash (1.38, 1.4, 1.43 and 1.30 $\%$ ) in longtail tuna stored at $0,8,25$ and $-18{ }^{\circ} \mathrm{C}$ at the end of the storage are shown in Table 2. Significantly $(\mathrm{p}<0.05)$ low loss of moisture was observed for tuna stored at -18 ${ }^{\circ} \mathrm{C}$, and the loss was higher at $25{ }^{\circ} \mathrm{C}$ compared to 0 and 8 ${ }^{\circ} \mathrm{C}$. The final values for moisture content in all the storage temperatures were significantly lower $(p<0.05)$ than the initial value. Reduction in fat content was noticed at -18 ${ }^{\circ} \mathrm{C}$, however, unlike moisture content, $25^{\circ} \mathrm{C}$ resulted in a higher fat content. At the end of the storage period 0 , 8,25 and $-18{ }^{\circ} \mathrm{C}$ showed significantly higher values for fat content than the initial value. Protein contents did not change significantly for the longtail tuna fish at different storage temperatures. However, tuna fish stored at -18 and $8{ }^{\circ} \mathrm{C}$ showed less and more protein contents, respectively, at the end of the storage. Final values for ash contents were significantly lower in all the storage temperatures than their initial value. There were only minor differences among 0,8 and $25{ }^{\circ} \mathrm{C}$ for ash contents, however, $-18{ }^{\circ} \mathrm{C}$ exhibited a significantly $(\mathrm{p}<0.05)$ lower ash content.

\section{Changes in Histamine Concentration}

The histamine content of longtail tuna was negligible $(0.2$ $\mathrm{mg} / 100 \mathrm{~g}$ ) at the beginning of the experiment, as shown in Figure 1. Histamine production was strongly suppressed at $0{ }^{\circ} \mathrm{C}$ and no increase in the histamine concentration was observed up to day 4. Thereafter, the formation of histamine showed some fluctuations with time; however, increase in the histamine content was noticed from day 7 onwards, with the highest concentration of $4.808 \mathrm{mg} / 100$ $\mathrm{g}$ on day 11. A reduction in the amount of histamine was observed at the end of the storage on day 15 , reaching a value of $0.4 \mathrm{mg} / 100 \mathrm{~g}$. In this study, the histamine in longtail tuna muscle during the storage at $0{ }^{\circ} \mathrm{C}$ was lower than $5 \mathrm{mg} / 100 \mathrm{~g}$ even at the end of the storage (Fig. 1). An increase in histamine content was delayed for the longtail tuna at the refrigerated temperature of $8^{\circ} \mathrm{C}$ for the first three days reaching a value of $0.984 \mathrm{mg} / 100 \mathrm{~g}$, which was slightly higher than the value reported at $0{ }^{\circ} \mathrm{C}$. However, histamine significantly increased $(\mathrm{p}<0.05)$ on day 7 and rapidly increased on day 8 , reaching a value of $17.99 \mathrm{mg} /$ $100 \mathrm{~g}$ of fish and maintained until the end of the storage on day 10 . The values were nearly four times higher than the value reported for longtail tuna stored at $0{ }^{\circ} \mathrm{C}$. In contrast to the refrigeration temperature, histamine levels increased very rapidly at $25^{\circ} \mathrm{C}$, reaching $28.40 \mathrm{mg} / 100 \mathrm{~g}$ of tuna in 
Al-Busaidi and others

Table 1. Sensory assessment data sheet for longtail tuna (Tunnus tonggol).

\begin{tabular}{|c|c|c|c|c|}
\hline Serial No. & Physical Characteristics & Feature & Sensory Feature & Score \\
\hline \multirow[t]{13}{*}{1} & General & Appearance of surface & Very bright & 7 \\
\hline & & & Moderately bright & 6 \\
\hline & & & Slightly bright & 5 \\
\hline & & & Neither bright nor dull & 4 \\
\hline & & & Slightly dull & 3 \\
\hline & & & Moderately dull & 2 \\
\hline & & & Very dull & 1 \\
\hline & & Texture & Firm & 7 \\
\hline & & & Soft & 1 \\
\hline & & & (Rank between 7 and 1) & \\
\hline & & Slime & Very clear & 7 \\
\hline & & & Very slimy & 1 \\
\hline & & & (Rank between 7 and 1) & \\
\hline \multirow[t]{13}{*}{2} & Eyes & Surface & Not sunken & 3 \\
\hline & & & Slightly sunken & 2 \\
\hline & & & Sunken & 1 \\
\hline & & Eyeball & Very clear & 7 \\
\hline & & & Moderately clear & 6 \\
\hline & & & Slightly clear & 5 \\
\hline & & & Neither clear nor cloudy & 4 \\
\hline & & & Slightly cloudy & 3 \\
\hline & & & Moderately cloudy & 2 \\
\hline & & & Very cloudy & 1 \\
\hline & & Eye & Bright, clear intact & 3 \\
\hline & & & Bloody & 2 \\
\hline & & & damaged & 1 \\
\hline \multirow[t]{13}{*}{3} & Gills & Color & Bright red & 5 \\
\hline & & & Deep dark red & 4 \\
\hline & & & Dull red & 3 \\
\hline & & & Pale brown & 2 \\
\hline & & & Bleached & 1 \\
\hline & & Odor & Seaweedy & 5 \\
\hline & & & Neutral & 4 \\
\hline & & & Slightly fishy & 3 \\
\hline & & & Fishy & 2 \\
\hline & & & Ammonia (putrid odor) & 1 \\
\hline & & Slime & Very clear & 7 \\
\hline & & & Very slimy & 1 \\
\hline & & & (Rank between 7 and 1) & \\
\hline \multirow[t]{2}{*}{4} & Belly & Condition & Intact & 7 \\
\hline & & & Burst (Rank between 7 and 1) & 1 \\
\hline \multirow[t]{7}{*}{5} & Overall & Acceptance & Very acceptable & \\
\hline & & & Moderately acceptable & \\
\hline & & & Slightly acceptable & \\
\hline & & & Neither acceptable nor rejected & \\
\hline & & & Slightly rejected & \\
\hline & & & Moderately rejected & \\
\hline & & & Very rejected & \\
\hline
\end{tabular}


Table 2. Changes in the proximate composition in longtail tuna (Tunnus tonggol) stored at different temperatures.

\begin{tabular}{|c|c|c|c|c|}
\hline \multirow{2}{*}{ Storage days } & Moisture(\%) & Protein $(\%)$ & Fat $(\%)$ & Ash (\%) \\
\hline & Mean \pm SD & Mean \pm SD & Mean \pm SD & Mean \pm SD \\
\hline \multicolumn{5}{|c|}{$0^{\circ} \mathrm{C}$} \\
\hline 0 & $72.50 \pm 0.50$ & $23.19 \pm 0.05$ & $2.85 \pm 0.06$ & $1.52 \pm 0.03$ \\
\hline 1 & $74.05 \pm 0.34$ & $23.03 \pm 0.04$ & $2.37 \pm 0.02$ & $1.51 \pm 0.01$ \\
\hline 3 & $75.30 \pm 0.20$ & $21.67 \pm 0.01$ & $2.48 \pm 0.01$ & $1.34 \pm 0.01$ \\
\hline 4 & $73.20 \pm 0.55$ & $23.62 \pm 0.41$ & $2.41 \pm 0.01$ & $1.35 \pm 0.02$ \\
\hline 7 & $71.05 \pm 0.05$ & $24.06 \pm 0.09$ & $3.10 \pm 0.03$ & $1.47 \pm 0.01$ \\
\hline 8 & $73.55 \pm 0.35$ & $23.10 \pm 0.58$ & $2.61 \pm 0.04$ & $1.40 \pm 0.04$ \\
\hline 9 & $73.15 \pm 0.65$ & $23.11 \pm 0.32$ & $2.69 \pm 0.09$ & $1.37 \pm 0.01$ \\
\hline 10 & $71.75 \pm 1.25$ & $24.75 \pm 0.14$ & $2.80 \pm 0.03$ & $1.40 \pm 0.02$ \\
\hline 11 & $72.05 \pm 0.65$ & $24.72 \pm 0.37$ & $2.70 \pm 0.02$ & $1.46 \pm 0.32$ \\
\hline 14 & $71.65 \pm 1.75$ & $25.05 \pm 0.02$ & $2.84 \pm 0.01$ & $1.12 \pm 0.01$ \\
\hline 15 & $71.45 \pm 0.28$ & $23.89 \pm 0.11$ & $3.02 \pm 0.09$ & $1.38 \pm 0.02$ \\
\hline \multicolumn{5}{|c|}{$8^{\circ} \mathrm{C}$} \\
\hline 0 & $72.50 \pm 0.50$ & $23.19 \pm 0.05$ & $2.85 \pm 0.06$ & $1.52 \pm 0.03$ \\
\hline 1 & $73.60 \pm 0.10$ & $23.33 \pm 0.02$ & $2.49 \pm 0.06$ & $1.56 \pm 0.01$ \\
\hline 2 & $70.95 \pm 0.25$ & $23.24 \pm 0.02$ & $3.08 \pm 0.02$ & $1.49 \pm 0.01$ \\
\hline 3 & $74.30 \pm 0.10$ & $21.82 \pm 0.01$ & $2.89 \pm 0.10$ & $1.38 \pm 0.04$ \\
\hline 4 & $73.70 \pm 0.40$ & $23.29 \pm 0.23$ & $2.59 \pm 0.03$ & $1.37 \pm 0.04$ \\
\hline 7 & $73.20 \pm 0.28$ & $23.12 \pm 0.31$ & $3.24 \pm 0.08$ & $1.38 \pm 0.08$ \\
\hline 8 & $71.15 \pm 0.25$ & $24.37 \pm 0.23$ & $3.29 \pm 0.06$ & $1.41 \pm 0.01$ \\
\hline 9 & $72.25 \pm 0.25$ & $24.21 \pm 0.15$ & $3.03 \pm 0.02$ & $1.30 \pm 0.03$ \\
\hline 10 & $71.25 \pm 0.15$ & $24.00 \pm 0.19$ & $3.22 \pm 0.01$ & $1.40 \pm 0.01$ \\
\hline \multicolumn{5}{|c|}{$25^{\circ} \mathrm{C}$} \\
\hline 0 & $72.50 \pm 0.50$ & $23.19 \pm 0.05$ & $2.85 \pm 0.06$ & $1.52 \pm 0.03$ \\
\hline 1 & $71.90 \pm 0.70$ & $23.12 \pm 0.03$ & $3.69 \pm 0.02$ & $1.43 \pm 0.01$ \\
\hline 2 & $71.00 \pm 0.11$ & $23.15 \pm 0.26$ & $4.48 \pm 0.02$ & $1.43 \pm 0.01$ \\
\hline \multicolumn{5}{|c|}{$-18^{\circ} \mathrm{C}$} \\
\hline 0 & $72.50 \pm 0.50$ & $23.19 \pm 0.05$ & $2.85 \pm 0.06$ & $1.52 \pm 0.03$ \\
\hline 1 & $73.00 \pm 0.63$ & $23.15 \pm 0.42$ & $2.96 \pm 0.02$ & $1.50 \pm 0.01$ \\
\hline 4 & $72.10 \pm 0.55$ & $23.11 \pm 0.25$ & $2.86 \pm 0.04$ & $1.40 \pm 0.09$ \\
\hline 7 & $73.30 \pm 0.30$ & $23.62 \pm 0.11$ & $2.39 \pm 0.01$ & $1.47 \pm 0.03$ \\
\hline 9 & $73.30 \pm 0.90$ & $23.35 \pm 0.80$ & $2.55 \pm 0.09$ & $1.43 \pm 0.04$ \\
\hline 14 & $73.70 \pm 0.10$ & $23.77 \pm 0.17$ & $2.05 \pm 0.35$ & $1.42 \pm 0.06$ \\
\hline 18 & $73.55 \pm 0.45$ & $22.31 \pm 0.01$ & $2.46 \pm 0.06$ & $1.51 \pm 0.03$ \\
\hline 30 & $73.30 \pm 0.20$ & $23.09 \pm 0.04$ & $2.62 \pm 0.08$ & $1.46 \pm 0.01$ \\
\hline 60 & $73.40 \pm 0.23$ & $23.06 \pm 0.14$ & $2.93 \pm 0.04$ & $1.53 \pm 0.05$ \\
\hline 120 & $71.65 \pm 0.35$ & $23.52 \pm 0.27$ & $3.29 \pm 0.02$ & $1.59 \pm 0.06$ \\
\hline 180 & $72.15 \pm 0.35$ & $24.65 \pm 0.12$ & $2.82 \pm 0.04$ & $1.55 \pm 0.02$ \\
\hline 240 & $72.50 \pm 0.20$ & $23.42 \pm 0.03$ & $3.15 \pm 0.07$ & $1.54 \pm 0.01$ \\
\hline 300 & $73.05 \pm 0.75$ & $23.02 \pm 0.61$ & $2.62 \pm 0.05$ & $1.30 \pm 0.04$ \\
\hline
\end{tabular}



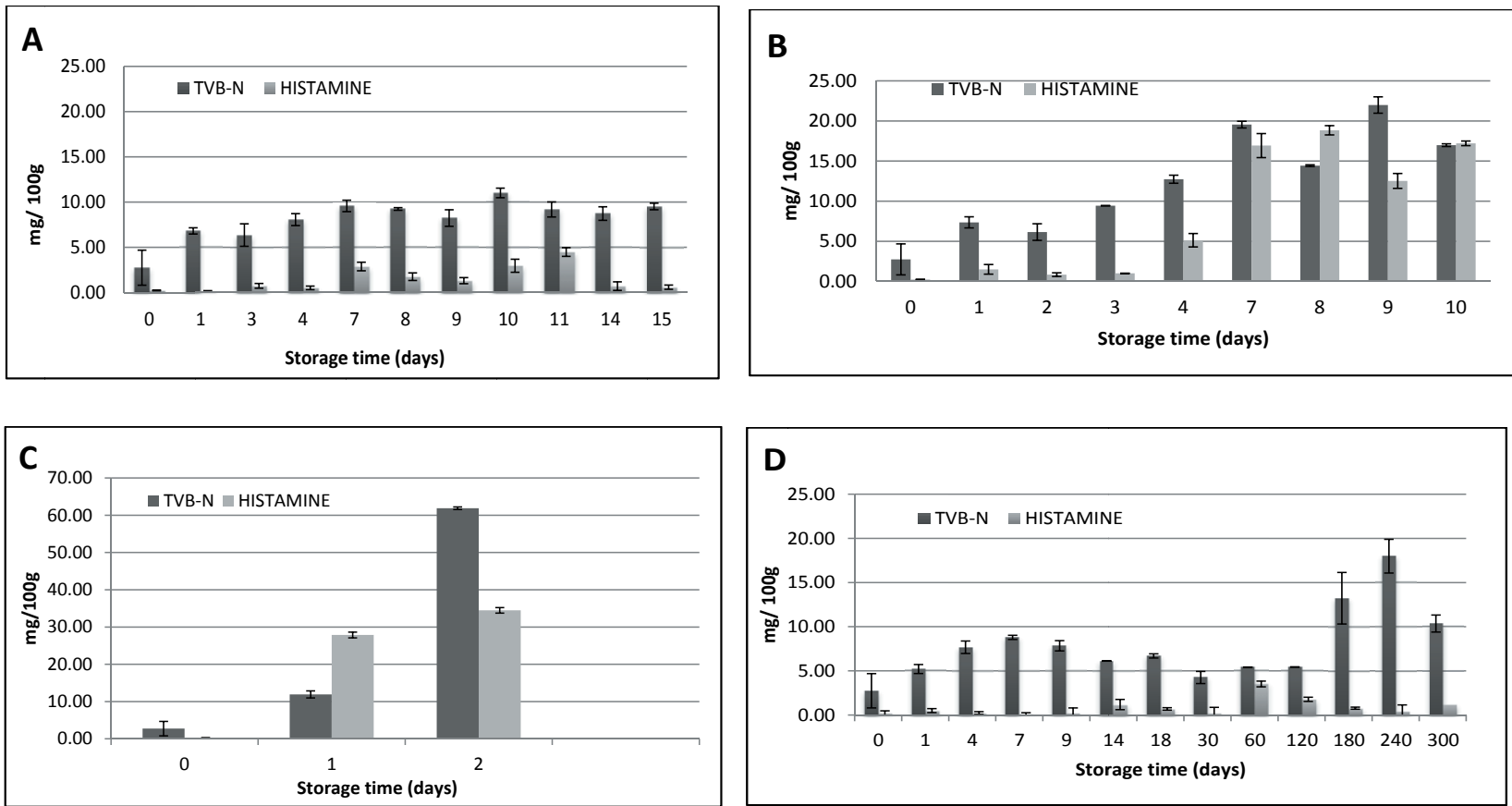

Figure 1. Changes in Histamine and TVB-N in longtail tuna stored at (A) $0{ }^{\circ} \mathrm{C}$, (B) $8{ }^{\circ} \mathrm{C}$ (C), $25^{\circ} \mathrm{C}$ and (D) $-18^{\circ} \mathrm{C}$.

one day of storage. The concentrations became 290 and 15 times higher than the histamine concentration reported at 0 and $8{ }^{\circ} \mathrm{C}$, respectively, and reached $34.99 \mathrm{mg} / 100 \mathrm{~g}$ of tuna at the end of the storage on day 2 . No significant changes ( $p>0.05)$ in the histamine concentrations were observed during frozen storage at $-18{ }^{\circ} \mathrm{C}$ for a period of one month. Thereafter, a significant increase $(\mathrm{p}<0.05)$ was observed during the second month reaching a level of $3.04 \mathrm{mg} / 100 \mathrm{~g}$ and decreased up to month eight. At the end of the storage period, a slight increase in the histamine concentration was observed. Safety with respect to the histamine was maintained for nearly 10 months in this experiment.

\section{Total Volatile Base Nitrogen (TVB-N)}

The initial TVB-N value for fresh longtail tuna was 2.741 $\mathrm{mg} / 100 \mathrm{~g}$ of fish in keeping with the quality of very fresh fish. An increasing trend in TVB-N was noticed in all the samples with storage time but the increase was not linear except in samples stored at $8{ }^{\circ} \mathrm{C}\left(\mathrm{r}^{2}=0.880\right)$ and $25{ }^{\circ} \mathrm{C}$ $\left(\mathrm{r}^{2}=0.968\right)$. A significant increase $(\mathrm{p}<0.05 \%)$ in TVB-N was noticed on day 1 and the value reached $11.03 \mathrm{mg} / 100$ $\mathrm{g}$ on day 10, thereafter, a slight decrease was observed at the end of storage period for fish stored at $0{ }^{\circ} \mathrm{C}$. At a temperature of $8{ }^{\circ} \mathrm{C}$, the TVB-N values increased more rapidly on day one (reaching a value of $7.35 \mathrm{mg} / 100 \mathrm{~g}$ ) and increased slowly but fluctuated with time reaching a maximum value of $21.99 \mathrm{mg} / 100 \mathrm{~g}$ on day 9 . At the end of the storage period the value was $16.98 \mathrm{mg} / 100 \mathrm{~g}$. A slow increase in the TVB-N was observed for samples stored at $-18{ }^{\circ} \mathrm{C}$ reaching a maximum value of $17.98 \mathrm{mg} / 100 \mathrm{~g}$. A slight reduction in the TVB-N was observed at the end of the storage. The values were always below the level of $30-40 \mathrm{mg} / 100 \mathrm{~g}$ declared for good quality fish. In contrast to the refrigerated samples, the TVB-N value increased sharply on day 1 for the longtail tuna stored at $25{ }^{\circ} \mathrm{C}$ reaching a value of $12.59 \mathrm{mg} / 100 \mathrm{~g}$ and at the end of the storage period the value reached a level of $62.12 \mathrm{mg} / 100$ $\mathrm{g}$ which is above the rejection limit of $40 \mathrm{mg} / 100 \mathrm{~g}$ set for TVB-N (Directive 95/149/EEC).

\section{Sensory Evaluation}

According to the sensory analysis, the initial samples were of good quality, indicated by the value for raw tuna of $6.3 \pm$ 0.51 (Fig. 2). The mean sensory score and standard deviation for overall acceptance of longtail tuna is depicted in Figure 2 . Storage temperature significantly $(p<0.05)$ influenced the overall acceptance and limited the shelf life of longtail tuna to 15,4 and less than one day during storage at 0,8 and $25^{\circ} \mathrm{C}$, respectively. The overall acceptance was nearly 10 months for longtail tuna stored under frozen storage.

\section{Discussion}

\section{Proximate Composition}

In the present study, the values of proximate composition were within the range reported earlier for commercial-size tuna fish in different waters (Mazorra-Manzano et al., 2000; Begona et al., 2006). Generally, storage time and temperature significantly $(\mathrm{p}<0.05)$ affect the proximate composition. Begona et al. (2006) reported a low loss of moisture for tuna fish stored at $-18^{\circ} \mathrm{C}$.

\section{Histamine Concentration}

Generally, histamine production showed different patterns at the four different storage temperatures, which indicates that storage temperature may have an effect on histamine 

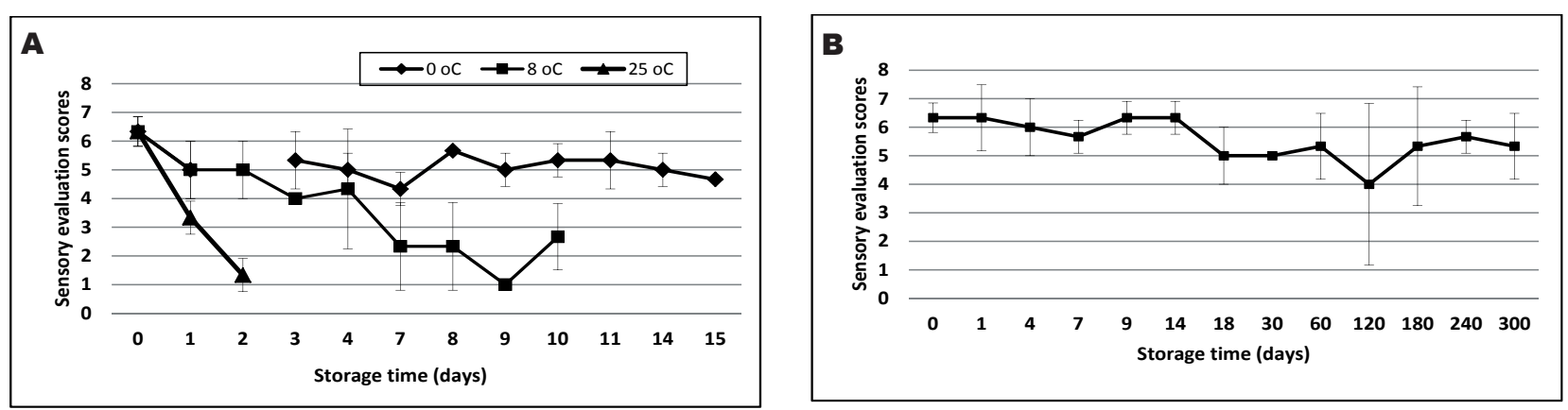

Figure 2. Changes in Sensory score (overall acceptance) of longtail tuna during storage at (A) 0,8 and $25^{\circ} \mathrm{C}$ and $(\mathrm{B})-18^{\circ} \mathrm{C}$.

production. Also, fluctuation with time was noticed in all the storage temperatures. Silva et al. (1998) reported $<0.1 \mathrm{mg} / 100 \mathrm{~g}$ of histamine for bigeye tuna species and skipjack tuna species at the beginning of their study. Our findings agree with that study, and the concentration was well below the FDA limit of $5 \mathrm{mg} / 100 \mathrm{mg}$. Storage temperatures significantly inhibited the formation of histamine at 0 and $8{ }^{\circ} \mathrm{C}$. The reduction of histamine with time of storage could be due to its decomposition once it was produced (Guizani et al., 2005). Sato et al. (1994) reported that the histamine formation also depends on the presence of histamine decomposition bacteria within the flora along with histamine forming bacteria. They noticed that, initially, histamine accumulated in the fish stored at $5{ }^{\circ} \mathrm{C}$ and then the levels started decreasing and disappearing when the count of histamine decomposing bacteria exceeded $10^{6}$ cells/g. It could also be due to the histaminases activity in the spoilage bacteria that may be responsible for the decline observed in longtail tuna after 11 days. Lopez-Sabater et al. (1995) found in bigeye tuna that histamine content declined once it reached its maximum level. However, in our study, notable amounts were not detected for up to 15 days of storage in ice. Safety of longtail tuna with respect to the histamine for up to four days at $8{ }^{\circ} \mathrm{C}$ agreed well with that of bigeye tuna, where four days at the same temperature were reported by Lopez-Sabater et al. (1995).

The histamine formation was increased at a faster rate in the longtail tuna samples stored at $25^{\circ} \mathrm{C}$. Increase in histamine formation is assumed to occur as a result of the growth of psychrotrophic or psychrophilic bacteria (Bennour et al., 1991; Vagelis et al., 2007). Stratton and Taylor (1991) stated that, the enteric bacteria are the most prolific histamine producers in fish when they are maintained at temperatures greater than $4^{\circ} \mathrm{C}$. Also, once the enzyme histidine decarboxylase has been formed, it can be active at or near refrigeration temperatures (FDA, 2001). Storage at $25^{\circ} \mathrm{C}$ encouraged the rapid histamine formation reaching the toxicity level within one day. This could be due to mesophiles, which are the most prolific histamine formers. In addition, histidine decorboxylase activity is favored at temperatures higher than $15{ }^{\circ} \mathrm{C}$. Lehane and Olley (2000) correlated the rapid histamine formation at $20{ }^{\circ} \mathrm{C}$ with the growth of Proteus morganii, which was found to grow better and to be the main histamine producer at $24-30{ }^{\circ} \mathrm{C}$. Unlike histamine decomposition at $0{ }^{\circ} \mathrm{C}$, no decomposition took place at $25{ }^{\circ} \mathrm{C}$, which implies that, such a high temperature might inhibit the growth of histamine decomposing bacteria (Sato et al., 1994). Our results agreed well with previous findings by Silva et al. (1998) and Guizani et al. (2005) who found rapid histamine accumulation in bigeye tuna, skip jack tuna and yellow fin tuna where safety was maintained for only one day at 22 and $20{ }^{\circ} \mathrm{C}$, respectively. It is possible that components, chemical or enzymatic, break down the biogenic amines faster than they can be produced at these temperatures, but then the components responsible for breaking down biogenic amines are either used up, or inactivated, whereas the enzymes producing biogenic amines remain active for a longer period of time. The histamine formation was very slow for the tuna samples stored at $-18{ }^{\circ} \mathrm{C}$. Storage time at frozen temperatures strongly controlled the formation of histamine. This could be due to the freezing temperature, which probably kills the freeze sensitive histamine producing bacteria (BenGigirey et al., 1998). At the same time, a slight increase in histamine concentration at this temperature could be due to the retention of histidine decorboxylase activity in frozen tuna which may increase histamine on thawing.

The histamine concentration in tuna at 0 and $-18{ }^{\circ} \mathrm{C}$ were lower than the health hazard level of $5 \mathrm{mg} / 100 \mathrm{~g}$, fixed by the FDA (2001), and the legal limit of $10 \mathrm{mg} / 100$ g fixed by European Community and Omani regulations. However, at 8 and $25^{\circ} \mathrm{C}$ the histamine levels were above the allowable limit after four days and $24 \mathrm{hrs}$, respectively, and characterized as unsuitable for consumption. Shakila et al. (2003) found a histamine content above the FDA maximum allowable limit of $5 \mathrm{mg} / 100 \mathrm{~g}$ after $12 \mathrm{hrs}$ in Rastrelliger kanagurta and after 15 hrs in Sardinella fimbriata stored at ambient temperature $\left(32^{\circ} \mathrm{C}\right)$.

The safe shelf life of scombrotoxin forming species is dependent upon the harvesting methods, the onboard handling and the time/temperature exposures throughout the processing, transit and storage. There are several factors affecting the probability of occurrence of histamine fish poisoning and among them, post-catch 
contamination, inadequate chill storage or freezing and thawing procedures can be listed (Lehane and Olley, 2000). In fish subjected to elevated temperatures even for shorter periods, a large population of bacteria is soon established. During subsequent refrigeration, although bacterial growth ceases, residual enzyme activity continues slowly and histamine levels can increase (Stratton and Taylor, 1991). In this study, tuna showed histamine concentrations defined as safe for consumption at 0 and $-18{ }^{\circ} \mathrm{C}$, possibly toxic and probably toxic when stored at 8 and $25^{\circ} \mathrm{C}$, respectively.

\section{TVB-N}

Significant differences $(\mathrm{p}<0.05)$ in TVB-N values were observed for longtail tuna stored at 0 and $8^{\circ} \mathrm{C}$. This was probably due to the influence of storage temperatures. Among the four different storage temperatures, slow increases in the levels of TVB-N were observed for longtail tuna stored at $-18{ }^{\circ} \mathrm{C}$; followed by $0{ }^{\circ} \mathrm{C}$. The relatively low increase in the TVB-N value could be due to the effectiveness of low temperatures on the growth of TVB-N producing bacteria. Maximum amounts and rapid increase were found for the longtail tuna samples kept at $25^{\circ} \mathrm{C}$; which indicates that, ambient temperature favoured the growth of TVB-N producing bacteria. Silva et al. (1998) reported $64 \mathrm{mg} / 100 \mathrm{~g}$ of TVB-N for skipjack tuna at $22{ }^{\circ} \mathrm{C}$ at the end of the storage period on third day. Connell (1990) reported that a maximum of 35-40 $\mathrm{mg} / 100 \mathrm{~g}$ is usually regarded as the limit of acceptability; however, in the present study TVB-N values for tuna samples were well within the suggested limit throughout the storage period, except, for samples stored at $25^{\circ} \mathrm{C}$. Figure 1 shows the TVB-N values obtained during the storage period at different temperatures. TVB-N values were found to increase linearly with time at $8\left(r^{2}=0.880\right)$ and $25^{\circ} \mathrm{C}\left(\mathrm{r}^{2}=0.968\right)$. However, an insignificant $(\mathrm{p}>0.05)$ increment in TVB-N values was observed with time at 0 and $-18{ }^{\circ} \mathrm{C}$, which could denote low bacterial activity. Our results were in agreement with the observation made by Mazorra-Manzano et al. (2000) for skipjack tuna muscle during iced storage. According to our results, changes in TVB-N content during storage of tuna at 0 and $8{ }^{\circ} \mathrm{C}$ did not reflect the quality index even though the samples were rejected by sensory evaluation.

\section{Sensory Evaluation}

Fish were rejected by the panel members very early even though the TVB-N value did not exceed the limit of 30-40 $\mathrm{mg} / 100 \mathrm{~g}$. Figure 3 shows the relationship of the overall acceptability of fish by sensory evaluation with pooled values of TVB-N and histamine.

Poor correlation $\left(r^{2}=0.472\right)$ was observed between overall acceptance and pooled TVB-N value during storage at four different temperatures indicating that the fish was rejected by the sensory panel before the fish reached the stage of decomposition. At the same time, correlation $\left(\mathrm{r}^{2}=0.647\right)$ was observed between sensory score and histamine formation and the correlation was greater at $8\left(r^{2}=0.717\right)$ and $25{ }^{\circ} \mathrm{C}\left(r^{2}=0.948\right)$. However, no correlation was found at $0^{\circ}$ and $-18^{\circ} \mathrm{C}$. These results agreed with Guizani et al. (2005) who reported a linear relationship between sensory score and histamine for yellowfin tuna stored at the same temperature. During storage at $0{ }^{\circ} \mathrm{C}$ longtail tuna were rejected by the panelists before histamine reached a toxic level of $5 \mathrm{mg} / 100 \mathrm{~g}$ fish (FDA, 2001). This observation agreed with the findings of Guizani et al. (2005) for storage of tuna fish at $0{ }^{\circ} \mathrm{C}$ and Lopez et al. (1995) for storage of tuna at $0{ }^{\circ} \mathrm{C}$; however, at $8{ }^{\circ} \mathrm{C}$ the fish maintained its safety up to the fourth day, that was well correlated with sensory score for overall acceptance. The loss of shelf life of longtail tuna correlated with the loss of safety with respect to histamine formation of longtail tuna when stored at 8 and $25^{\circ} \mathrm{C}$. However, tuna stored at 0 and $-18{ }^{\circ} \mathrm{C}$ maintained their safety throughout the storage period. This could be due to decomposition of histamine at this temperature. The optimum temperature for the majority of the histamine formers is $25^{\circ} \mathrm{C}$.

Regression analysis of histamine and other quality characteristics of longtail tuna revealed a correlation between histamine concentrations and sensory analysis at 8 and $25^{\circ} \mathrm{C}$; but not at 0 or $-18^{\circ} \mathrm{C}$, even though the fish were rejected by the sensory panel. No correlation was observed between histamine and TVB-N formation, except, at $25^{\circ} \mathrm{C}$ $\left(r^{2}=0.699\right)$. Measurements of volatile basic nitrogen were not adequate for estimating the extent of a histaminerelated health hazard. It was found that decomposition of longtail tuna at all the storage temperatures progressed faster than histamine formation.

\section{Conclusion}

Histamine and volatile amine (TVB-N) increased progressively during storage, but the rate of change varied with temperature. Histamine production was suppressed significantly $(\mathrm{p}<0.05)$ and lower than the FDA maximum allowable limit of $5 \mathrm{mg} / 100 \mathrm{~g}$ at 0 and $-18{ }^{\circ} \mathrm{C}$. With regard to the histamine toxicity, histamine production was very high at 8 and $25^{\circ} \mathrm{C}$. Taking into consideration public health safety, appropriate storage temperature at preferably $<4^{\circ}$ $\mathrm{C}$ and appropriate handling of tuna fish are necessary for delaying histamine production and preventing histamine poisoning outbreaks. Also, freezing the tuna prior to processing and storage reduced the histamine production. The histamine content did not show any correlation with the TVB-N value except, at $25{ }^{\circ} \mathrm{C}$. However, the correlation was closer with sensory changes at 8 and 25 ${ }^{\circ} \mathrm{C}$. TVB-N did not indicate the degree of freshness for fish stored at low temperatures $\left(0\right.$ and $\left.-18^{\circ} \mathrm{C}\right)$. Estimation of TVB-N was not adequate for estimating the degree of histamine-related health hazards. The refrigeration temperature during storage is very critical to reducing histamine formation and also it is necessary to determine histamine content in order to control a potential health hazard. The loss of shelf life of longtail tuna correlated with the loss of safety with respect to histamine formation 

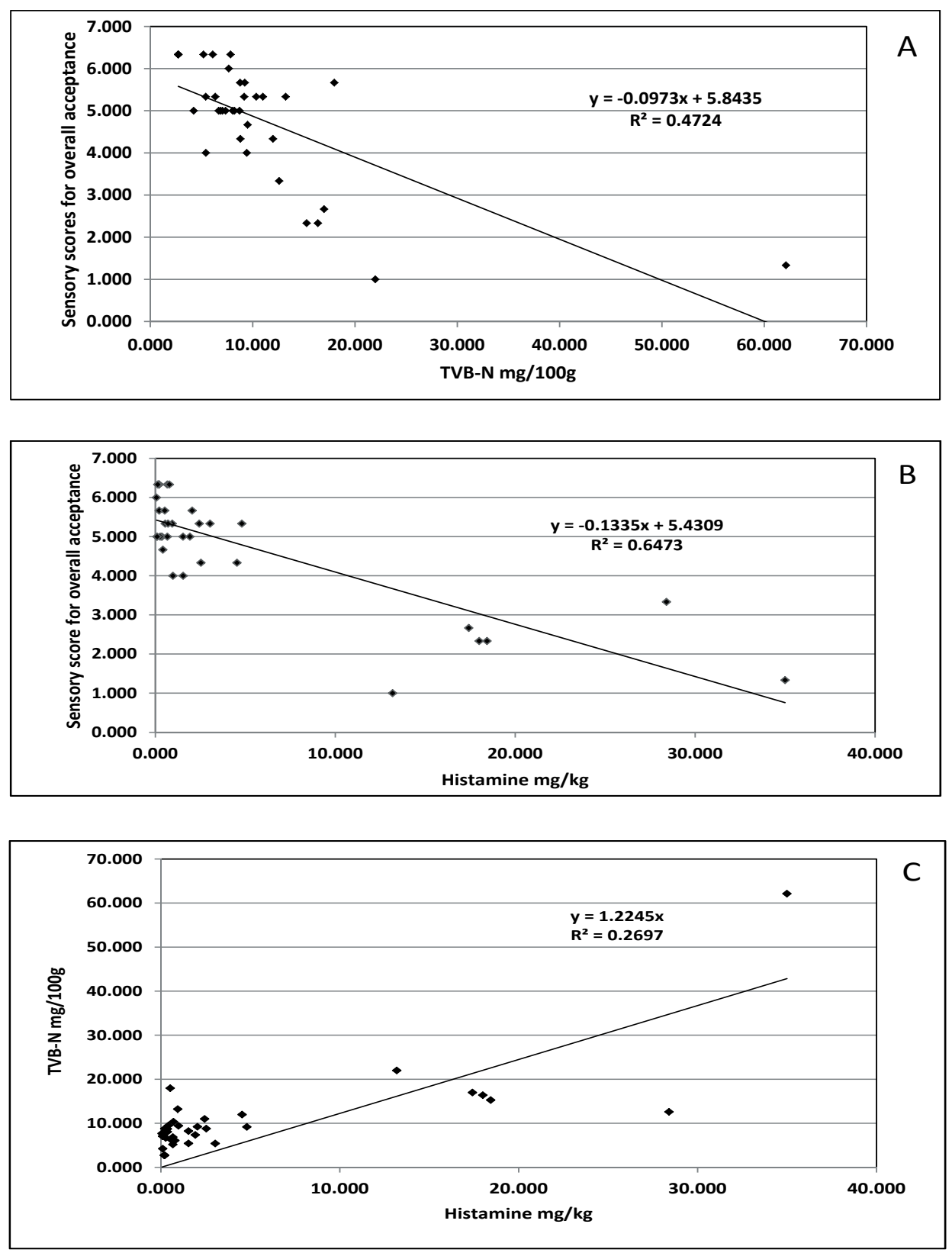

Figure 3. Relationship between (A) sensory score and TVB-N, (B) sensory score and histamine, and (C) TVB-N and histamine of longtail tuna stored at $0,8,25$ and $-18{ }^{\circ} \mathrm{C}$.

at 8 and $25{ }^{\circ} \mathrm{C}$; however, tuna stored at 0 and $-18{ }^{\circ} \mathrm{C}$ maintained their safety throughout the storage period.

\section{Acknowledgements}

We would like to thank Mehdia Al-Zidjali, Alia Al-Zidjali and Nada Al-Abri of Fishery Quality Control Centre, Oman, for their constant assistance and contribution in sample preparation and analysis during this project.

\section{References}

AOAC. 1993. Official Methods of Analysis, $14^{\text {th }}$ Ed. Vol. II. Association of Official Analytical Chemists. Arlington, Va. Chap 35:1-8.
Bartholomew, B.A., P.R. Berry, J.C. Rodhouse, R.J. Gilbert, and C.K. Murray. 1987. Scombrotoxic fish poisoning in Britain: features of over 250 suspected incidents from 1976 - 1986. Epidemiology and Infection 99:775-782.

Ben-Gigirey,B., J.M. Vieites Bapista De Sousa, T.G. Villa, and J. Barros-Velasquez. 1998. Changes in biogenic amines and microbiological analysis in albacore (Tunnus alalunga) muscle during frozen storage. Journal of Food Protection 61:608-615.

Begona, B.G., M. Juan, B.D.S. Vieites, G. Tomas, and G.B.V. Villa. 2006. Chemical changes and visual appearance of Albacore Tuna as related to frozen storage. Journal of Food Science 64:20-24. 
Bennour, M.E.L., A. Marrakchi, N. Bouchriti, A. Hamama, and M. El Quasea. 1991. Chemical and microbiological assessments of mackerel (Scomber scombrus) stored in ice. Journal of Food Protection 54:789-792.

Bremmer, H.A., J. Olley, and A.M.A. Vail. 1987. Estimating time temperature effect on rapid systematic sensory method. In: Proceedings of an International Symposium on Seafood Quality Determination, D.E. Kramer and J.Liston (Editors), 413-434. Alaska, USA, Amsterdam:Elsevier.

Commission Regulation 2073/2005/EC of 15 November 2005. 2005 Official Journal L 338/1, 22/12/2005.

Connel, J.J. 1990. Methods of Assessing and Selecting for Quality. In: Control of Fish Quality ( ${ }^{\text {rd }}$ Edition), 122-150, Fishing News Books, Oxford.

Damoglu, A.P. 1979. A comparison of different methods of freshness assessment of herring. In: Advances in Fish Science and Technology. Paper presented at the Jubilee Conference of the Torry Research Station, Aberdeen, Scotland, 22-23 July 1979. Fish Review Books Ltd. Farnham, Surrey, England. 394-399.

Dewaal, C.S., G. Hicks, K. Barlow, L. Alderton, and L. Vegosen. 2006. Foods associated with foodborne illness outbreaks from 1990 till 2003. Food Protection Trends 26:466-473.

Food and Drug Administration (FDA). 2001. Scombrotoxin (histamine) formation. In: Fish and Fisheries Products Hazards and Controls Guidance, ( $3^{\text {rd }}$ Edition), 83-102, Office of Seafood, Washington, DC.

Guillen-Velasco, S., E. Ponce-Alquicira, A. FarresGonzalez Saravia, and I. Gerrero-Legarreta. 2004. Histamine production by two enterobacteriaceae strains from tuna (Thunnus thynnus) and jack mackerel (Trachurus murphyii). International Journal of Food Properties 7:91-103.

Guizani, N., M.A. Al-Busaidy, I.M. Al-Belushi, A. Mothershaw, and M.S. Rahman. 2005. The effect of storage temperature on histamine production and freshness of yellowfin tuna (Thunnus albacares). Food Research International 38:215-222.

Lehane, L. and J. Olley. 2000. Review: histamine fish poisoning revisited. International Journal of Food Microbiology 58:1-37.

Lopez-Sabater, E., J. Rodrigues-Jerez, M. HernadezHerrrero, A. Roig-Sagues, and M. Mora-Ventura. 1995. Sensory quality and histamine formation during controlled decomposition of tuna (Thunnus thynnus). Journal of Food Protection 59:167-174.

Mazorra-Manzano, M.A., R. Pacheco-Aguilar, E.I. DiazRojas, and M.E. Lugo- Sanchez. 2000. Post mortem changes in black skipjack muscle during storage in ice. Journal of Food Science 65:774-779.
Ministerial Decision No.12/2009. 2009. Fisheries Quality Control Regulation, Ministry of Fisheries Wealth, Muscat, Sultanate of Oman.

Murray, C.K. and G. Hobbs. 1982. Scombrotoxin and scombrotoxin-like poisoning from canned fish. Journal of Hygiene 88:215-220.

Noltkamper, D. 2006, Toxicity, marine-histamine in fish, [eMedicin]. Available at: http://www.emedicine.com/ ped/topic1012.htm. Accessed November 19, 2007.

Sato,T., T. Fujii, T. Masuda, and M. Okuzumi. 1994. Changes in number of histamine metabolic bacteria and histamine content during storage of common mackerel. Fisheries Science 60:299-302.

Sikorski, Z.E. 1994. The Myofibrillar Proteins in Seafood. In: Seafood Proteins, Z.E. Sikorski, B.S. Pan and F. Shahidi (Editors), Chapman and Hall, New York.

Shalaby, A.R. 1996. Significance of biogenic amines to food safety and human health. Food Research International 29:675-690.

Shakila, R.J., K. Vijayalakshmi, and G. Jeyasekaran. 2003. Changes in histamine and volatile amines in six commercially important species of fish of the Thoothukkudi coast of Tamilnadu, India stored at ambient temperature. Food Chemistry 3:347-352.

Silva, C., D. Ponte, and M. Dapkevicius. 1998. Storage temperature effect on histamine formation in big eye tuna and skipjack tuna. Journal of Food Science 63: 644-647.

Steve, L.T., E.S. Jayne, and A.N. Julie. 1989. Histamine poisoning (Scombroid Fish Poisoning): an allergy-like intoxication. Clinical Toxicology 27:225-240.

Stratton, J.E. and S.L. Taylor. 1991. Scombroid poisoning. In: Microbiology of Marine Food Products, D. Ward and C. Hackney (Editors), 331-351, Spectrum, New York, N.Y.

Taylor, S., E. Lieber, and M. Leatherwood. 1978. A simplified method for histamine analysis of foods. Journal of Food Science 43:247-50.

Taylor, S.L. 1986. Histamine food poisoning - Toxicology and clinical aspects. Critical Reviews in Toxicology 17: 91-128.

Ten Brink, B., C. Damink, H.M.L.J. Joosten, and J.H.J. Huis In'T Veld. 1990. Occurrence and formation of biologically active amines in foods. International Journal of Food Microbiology 11:73-84.

Yeh, C.P.S., R. Nickelson II, and G. Finne. 1978. Ammonia producing enzymes in white shrimp tails. Journal of Food Science 43:1400-1401.

Received: October 3, 2010

Accepted: February 20, 2011 